\title{
A RESEARCH ON THE RELATIONSHIP BETWEEN INDIVIDUAL AND SOCIAL INNOVATIVENESS: THE CASE OF SELCUK UNIVERSITY*
}

\author{
BİREYSEL VE SOSYAL YENILIIKÇİLİK İLİŞKİSI ÜZERINE BİR ARAŞTIRMA: \\ SELÇUK ÜNIVERSITESİ ÖRNEĞİ
}

\author{
Vural ÇAĞLIYAN** \\ Eldana ESENALIEVA*** \\ Melis ATTAR ${ }^{* * * *}$
}

\begin{abstract}
In today's competitive environment, innovativeness is considered to be one of the most important means of increasing social welfare while being a competitive advantage for organizations. Additionally, innovativeness helps organizations in differentiating themselves on the market and providing value with advanced products and services as well as solving customer problems. Within this framework, it is necessary to emphasize an individual's openness to changes and one's ability to innovate. It is supposed that the individual might provide positive changes to the organization and society, as well as solve problems arising in it by considering innovation from both managerial and social perspectives in case he/she wants to innovate. Social innovation regards to innovative practices and services while meeting social needs and providing solutions to such social issues as women empowerment, training for disabled people, waste management etc. There are many studies in the literature that examined the relationship between individual innovativeness and creative behavior. However, as literature review did not demonstrate any research on the relationship between individual innovativeness and generation of social value, this study aims to contribute to the literature by filling this gap. In this context, the main purpose of this research is to be the leading study in the literature by examining the relationship

* Received: 9.11.2018; Accepted: 25.02.2019

** Selcuk University, Department of Production Management and Marketing, ORCID ID: 0000-0002-7964-8840

*** Selcuk University, Department of Production Management and Marketing, ORCID ID: 0000-0002-2415-1984

**** Selcuk University, Department of International Trade, ORCID ID: 0000-0002-1299-7552
\end{abstract}


between individual and social innovativeness along with the causality relationship between these two variables. The survey method has been applied in this research. The results of the field study held on academicians who play an important role in the emergence and dissemination of innovation were evaluated along with the suggestions and limitations of the research. We find a statistically significant relationship between two variables and we conclude that individual innovativeness can be used to explain social innovativeness.

Keywords: Innovation, Individual Innovativeness, Social Innovativeness, Diffusion of Innovation.

JEL Codes: M10, M11, M14

\section{Öz}

Günümüzün rekabetçi yapısında yenilikçilik; işletmeler için rekabetçi bir avantaj sağlamanın, toplumsal olarak ise refahı artırabilmenin önemli araçlarından birisidir. Bununla birlikte araştırmalara göre yenilikçilik; örgütlere pazarda kendilerini farklılaştırma konusunda yardım etmekte, daha gelişmiş mal ve hizmetler ile değer sağlamakta ve müşteri sorunlarını çözmektedir. Bu çerçevede bireyin yeniliğe açık olması ve yenilik yapabilmesi hem toplum, hem örgüt için oldukça önemlidir. Bireyin yenilik yapmak istediği ve ona hazır olduğu zaman, yeniliği idari ve sosyal bakımından göz önüne alarak onun örgüt ve toplum içinde ortaya çıkan sorunları çözebildiği ve pozitif değişimleri sağlayacağı düşünülmektedir. Sosyal yenilik; yenilikçi uygulamalar ve hizmetler ile alakalı olup sosyal ihtiyaçları karşllamakla birlikte günümüzde önemli olan kadınların güçlendirme, programlar ve teknolojik uygulamalar aracılığıyla engelli insanların eğitim almaları, atık yönetimi, sürdürülebilir gelişim, içme suyu sağlaması ve kıtlık gibi sosyal sorunları çözmektedir. Bireysel yenilikçiliğin, yaratıcı davranış ile ilişkisi literatürde birçok çalışma ile tartışılmış ancak sosyal fayda yaratma ile ilişkisini irdeleyen bir çalışmaya rastlanmamıştır. Bu çalışma, literatüre bu boşluğu doldurarak katkı sağlamayı hedeflemektedir. Bu bağlamda çalışmanın temel amacı, bireysel yenilikçilik ile sosyal yenilikçilik arasındaki ilişkiyi tespit etmenin yanı sıra nedensel ilişkisini inceleyerek, literatürde öncül çalışmalardan biri olmaktır. Araştırmada veri toplama yöntemi olarak anket kullanılmıştır. Çalışmada, yeniliğin ortaya çıkmasında ve yayılmasında önemli rol oynayan akademisyenler üzerinde yapılan bir alan araştırmasının sonuçları değerlendirilmiş olup, öneriler ve kısıtlılıklar tartışılmıştır. Yapılan alan araştırması sonucunda akademisyenlerin bireysel yenilikçilik ile sosyal yenilikçilik düzeyleri arasında istatistiksel bakımdan anlamlı bir ilişkinin olduğu ve bireysel yenilikçiliğin sosyal yenilikçiliğin açıklanmasında kullanılabileceği tespit edilmiştir.

Anahtar Kelimeler: Yenilik, Bireysel Yenilikçilik, Sosyal Yenilikçilik, Yenilik Yayılımı.

JEL Kodları: M10, M11, M14

\section{INTRODUCTION}

The competitive environment requires organizations to respond to environmental changes by creating new products and services. Therefore, the innovative capacity of an individual can significantly affect the process of organization's adaptation to innovation and its success. 
Moreover, individual innovation can also be defined as a social practice which expands beyond business and depends on social requirements and regulations (Standing, Jackson, Larsen, Suseno, Fulford \& Gengatharen, 2016, p.45). Additionally, organizations with the high level of social consciousness (the degree to which organizations define success in terms of social wealth) react to social changes by the means of its innovativeness (Dibrell, 2015, p.600). As individuals are assumed to be the drivers of change and facilitators of creativity and learning in organizations from the individual innovativeness perspective (Gilbert, 2007, p.135), it is assumed that it is necessary for individuals to have innovative characteristics in order to adjust to innovations emerging in society. Thus, it is important to determine whether people with innovative potential can expose social innovative tendencies.

Being a foundation of any organization or community an individual plays an important role in the formation of new ideas and changes in that organization or community. In the business sector innovation is considered to be a significant competence of an individual that brings value (Waychal, Mohanty \& Verma, 2011, p.302). Likewise, it is assumed that innovations influencing members of our society and create social value depend on the ability of individuals to create change or innovate (Phillis, Deiglmeier, \& Miller, 2008, p.36; Hannan, English \& Silver, 1999, p.286). As innovation is commonly defined as creation and development of something new within a group, organization, society or country in terms of productivity and growth (Abernathy \& Clark, 1985, p.3; Heunks, 1998, p.263), policymakers work on fostering innovation for sustainable economic growth in countries (Al Mamun, Muniady, Yukthamarani, Noor Raihani Binti \& Mohamad, 2016, p.1100). Therefore, it can be supposed that innovation can expose a positive impact both on organizations and society.

Social innovations are defined as innovative activities that are aimed at meeting a social need which can take a form of corporate social responsibility in for-profit organizations (Phillips, Lee, Ghobadian, O’Regan \& James, 2015, p.430). Moreover, social innovation contributes to addressing the needs of society while increasing its welfare (Kocziszky \& Somosi, 2016, p.170). In addition, considering that innovation from the social perspective is a process that contributes to the development of society, social innovations are also likely to impose a positive effect on the individual. Moreover, social change is widely accepted to be forced by energetic, heroic and creative individuals (Mulgan, 2006, p.148). Therefore, it is important to know to what extent an individual is willing and ready to change, and how this change will affect individuals' innovations in society. In this context, the main purpose of this study is to examine the causal relationship between individual and social innovativeness. The field study is carried out on the academic staff of Selcuk University, Konya, Turkey, considering that the academicians are the pioneers and supporters of innovation.

In this context, firstly, the literature review on the notion of individual innovativeness is conducted. Following sections consider a detailed explanation of the phenomenon of social 
innovativeness and the relationship between individual and social innovativeness. Then, a research methodology is presented, followed by the results and conclusion sections.

\section{LITERATURE REVIEW}

\subsection{Innovation and Innovativeness}

There has been growing attention to the topic of innovation since the last century. Schumpeter was among the first ones to describe it as "the introduction of a new good" in 1934 (Salim Saji \& Ellingstad, 2016, p.257). Innovation can also be described as "an early implementation of an idea by an organization" (Pierce \& Delbecq, 1977, p.28) and "the creation and implementation of value through business models, products, services, processes, and systems in an organization" (Winby \& Worley, 2014, p.225).

Some scholars also state that innovation is a multi-stage process in which organizations transform ideas into improved products, services or processes in order to successfully advance, compete, differentiate themselves in the market (Baregheh, Rowley \& Sambrook, 2009, p.1334) and solve customer problems. By "increasing value for customers and producers" these processes have a positive impact on society (Lisetchi \& Brancu, 2014, p.88).

Innovation is a concept that is generally associated with technological progress, although it occurs in different areas. Pater and Lewandowska (2015, p.34) emphasize that innovation and innovativeness can be created with the help of business relationships with partners in public authorities and institutions as well as professional and social organizations. Innovativeness is considered to be "the degree to which an individual or another unit of adoption is relatively earlier in adopting new ideas than other members of a system" (Rogers, 1971, p.22). The speed of innovation adoption and implementation can put an organization one step ahead of its competitors. Therefore, organizations not only need to motivate their employees to innovate but to make them focus on their willingness to innovate and change.

\subsection{Individual Innovativeness}

Many definitions of innovation involve development and application of new ideas and dependency on creative ideas (Amabile, 1988, p.126). An organization needs to be open to creativity as well as to new products and services as organizations compete with the use of innovations created by their employees (Yesil \& Sozbilir, 2013, p.542). Therefore, innovation has become one of the important sources of organizations' competitive power.

Individual characteristics play an important role in the process of accepting innovations. Individual innovation is based on personal qualities such as creativity, talent and exceptional intelligence (Shavinina \& Seeratan, 2003, p.32). Individual innovativeness depends on personal willingness to innovate and on positive tendency to make changes (Erdoğan \& Güneş, 
2013, p.3034). Individual innovativeness depends on leadership, desire, and commitment to innovation of organization's employees and consumers' openness to new products and services (Uzkurt, 2017, pp.30-183).

Rogers's S-shaped diffusion curve is widely used for the classification of individuals' levels of adopting innovations. The diffusion curve is divided by the categories that fit the ratio of the percentage of participants: Laggards, Late majority, Early majority, Early adopters, and Innovators. The curve rises gradually when there is a small number of people who adopt innovations, reaches its highest point as the half of the individuals in the system adopts innovation and slows while remaining individuals finally accept the innovation (Rogers, 1971, p.247). The classification of Rogers' adoption of innovations and its general characteristics are summarized in Table 1.

Table 1: The classification of adoption of innovation and its characteristics

\begin{tabular}{|l|l|}
\hline Class & Characteristics \\
\hline Innovators & $\begin{array}{l}\text { The essential feature of innovators is their bravery and their openness to new ideas and wider } \\
\text { social relations. In addition, innovators are ready to accept innovations despite their uncertainty. } \\
\text { Innovators also have the ability to perceive and implement technological information. In addition, } \\
\text { innovators have a very important place in the social system for adopting new ideas. }\end{array}$ \\
\hline Early Adopters & $\begin{array}{l}\text { Early adopters serve as role models for the majority of individuals in the system. Early adopters } \\
\text { are potential adopters of innovations and consult innovators before adopting innovations. Early } \\
\text { adopters apply new ideas and then transfer their evaluation to others. Thus, the early adopters play a } \\
\text { leading role for those who adopt the next innovations and gain the appreciation of others. }\end{array}$ \\
\hline Early Majority & $\begin{array}{l}\text { Early majority have an important place in the system because they provide a link between innovators } \\
\text { and late majority. The main feature of the early majority is that these people make prudent decisions } \\
\text { about adopting innovations. In fact, the early majority people are eager to adopt new ideas. But these } \\
\text { people need a little longer time to adopt innovations. }\end{array}$ \\
\hline Late Majority & $\begin{array}{l}\text { The main feature of the late majority is skepticism. The late majority people do not accept new ideas } \\
\text { until most of the individuals in the system adopt innovations. The late majority should be confident } \\
\text { that the ideas they will adopt are safe. }\end{array}$ \\
\hline Laggards & $\begin{array}{l}\text { Laggards are the last adopters of innovations. Their decisions are based on the decisions of previous } \\
\text { generations and they are suspicious of their decisions. They mainly interact with people who have } \\
\text { the same traditional views. Moreover, when laggards adopt new ideas, there can emerge a newer idea } \\
\text { which has already been adopted by innovators. }\end{array}$ \\
\hline
\end{tabular}

There are many studies which examined various factors that may affect the innovative behavior of an individual. Scott and Bruce (1994, p.601) found that there is a significant relationship between individual innovative behavior and leadership, support for innovation and career stage. Additionally, personal characteristics are also among the factors affecting individual innovativeness (Y1lmaz \& Bayraktar, 2014, p.3461).

There are many studies that examined the measurement of innovativeness. The increase of studies done in this field since the 1970s has led to the development of various consumer 
innovativeness scales that were divided into two groups of "life innovativeness" and "adoptive innovativeness" scales (Roehrich, 2004, p.673)

The consumer innovativeness scale developed by Manning, Bearden and Madden (1995, p.342) is based on consumer independent decision-making behavior (the degree to which an individual makes new product decisions independently) and consumer search for innovation (the individual's tendency to search for new product information). Steenkamp, Hofstede and Wedel (1999, p.56) defined consumer innovativeness as consumers' tendency to choose new products and new brands rather than stay with previous choices. Vandecasteele and Geuens (2010, p.308) developed a 4-dimensional and 20-item Motivation Consumer Innovativeness scale that considers hedonic, functional, social and cognitive sources of motivation.

Additionally, Wang and Ahmed (2004) have identified 5 basic areas (product innovativeness, market innovativeness, process innovativeness, behavioral innovativeness, and strategic innovativeness) that constitute global innovativeness and define organizational innovativeness as the ability to offer new products with innovative behavior.

However, the literature demonstrates only four main scales that considered innovativeness as a personality trait and measure individual innovativeness: The Jackson Personality Inventory, Kirton Adaption-Innovation Inventory, Innovativeness Scale developed by Hurt, Joseph and Cook (1977), and The NEO Personality Inventory (Goldsmith \& Foxall, 2003, p.326). The classification of innovation adopters made by Rogers (1962) is widely accepted in the literature; however, it does not provide any scale for measurement of innovativeness. Nevertheless, reliability and validity of the scale developed by Hurt et al. (1977) which was adapted to Turkish by Kılıçer and Odabaşı, is accepted and used by many researchers (Kıl1çer \& Odabaşı, 2010, p.152). Thus, in this study, it was decided to use the Individual Innovativeness Scale developed by Hurt et al. (1977) in order to measure an individual's desire to change.

\subsection{Social Innovativeness}

In the literature there is significant lack of research in the field of social innovation in comparison to business innovation, still linking it to the area of social entrepreneurship (Phillips et al., 2015, p.431), social inventions and related fields. The ability to find innovative solutions to social problems that is generally regarded as social innovativeness, considered to be a necessity in encountering such social problems as income inequality, climate change and poverty (van Wijk, Zietsma, Dorado, de Bakker \& Martí, 2018, p.2). Therefore, society needs to constantly seek new solutions and to be innovative. A social problem can be solved by a new, more effective, efficient, sustainable solution by creating a value that is transferred to the whole society which is accepted as social innovation (Phillis et al., 2008, p.36). 
The Young Foundation (2012, p.18) proposed the following determination of social innovations in the scope of The Theoretical, Empirical and Policy foundations for building Social İnnovation in Europe project (TEPSIE):

"Social innovations are new solutions (products, services, models, markets, processes, etc.) that simultaneously meet a social need (more effectively than existing solutions) and lead to new or improve capabilities and relationships and/or better use of assets and resources".

That is, social innovations are aimed at society's welfare and enhance society's capacity to act. They can take form of concepts, ideas, and organizations that meet the needs of society within the context of community development and health while strengthening the civil society (Salim Saji \& Ellingstad, 2016, p.258). Social innovation can assess projects in terms of innovation performance and evaluate innovativeness of organizations (Bund, Gerhard, Hoelscher \& Mildenberger, 2015, p.49) as organizations create more "sustainable products and services to meet social and environmental needs" that allows them to be "drivers for social change...while creating new markets" (London, 2012, p.221).

Despite that the social innovation as a term can be considered as new, social innovation itself have been existed for a long time taking the form of social initiatives in health, education, climate change, and related sectors. Industrialization and urbanization in the $19^{\text {th }}$ century brought social enterprise and innovation: microcredit, trade unions, model schools, and reading clubs. Then there was a wave of feminism, ecology and civil rights movements that led to innovations in governments and markets in 1960s-1970s (Mulgan, Tucker, Ali \& Sanders, 2007, p.9). This is European Social Innovation call presented several social innovation projects that tackled social and environmental need, had meaning for all stakeholders and created new and effective relationships in society that help identify social innovation. The examples of such include projects aimed at educational inequalities, employment of socially excluded groups, healthcare technology, an increase of legal rights, active involvement of people with disabilities in society etc. (European Commission, 2010, p.9) as well as Wikipedia, community services etc.

Nevertheless, scholars question the ways of fostering social innovation and conditions for it. Mulgan (2006, p.150) emphasizes that the most effective way to encourage social innovation lies through understanding that an individual or an institution can solve own problems in a competent way. Leadbeater $(2007$, p.14) suggests that government needs to support a social enterprise as a means of social innovation by encouraging social responsibility from business customers, promoting social innovation in public services and supporting social entrepreneurs. Bright and Godwin (2010, p.180) indicated that social innovation needs virtuous intent as the foundation. Unceta, Castro-Spila and García Fronti (2016, pp.4-10) examined dimensions of social innovation at different levels in RESINDEX (Regional Social Innovation Index) model indicating individual, organizational and regional approach as the 
perspectives that can be used to measure existing approaches and social innovation in four key dimensions: "acquisition of knowledge, development of innovations, impact assessment and governance of social innovation".

In 1995, Roehrich developed the Hedonic and Social Innovation (HSI) scale that consists of two dimensions. Hedonic dimension depends on the person's need for stimulation while the social dimension is related to the need for human's uniqueness. In addition, the hedonic dimension is concerned with purchasing and testing, while the social dimension covers both purchasing and information acquisition processes. The items of the HSI scale are demonstrated as follows (Roehrich, 2004, p.674):

1. I am more interested in buying new than known products.

2. When I see a new product in a store I often buy it just to see what it is like.

3. I think that we must buy a product that has just been launched.

4. I like to buy new and different products.

5. New products excite me.

6. I like to test and try the latest innovations.

7. I am usually among the first to try new products.

8. I know more than others on new products.

9. I try new products before my friends and neighbors.

However, as this scale has a hedonic dimension along with the social one, this scale cannot be considered as an appropriate to measure predisposition to seek ways of making positive change and meeting economic and social needs through services, processes and entrepreneurial activities. The field of social innovativeness has dragged the interest of researchers during the last several decades. Nevertheless, Halaç, Eren and Bulut (2014, p.173) have discovered that there was a lack of social innovativeness scale in the literature and decided to fill this gap by developing Social Innovativeness Scale used in this study as the only social innovativeness scale found during the literature review.

\subsection{The Relationship between Social Innovativeness and Individual Innovativeness}

The literature review demonstrated that previous research has focused either on social innovation or on individual innovativeness in a separate way. Nevertheless, as social innovation is often related to social entrepreneurship and social enterprise as a mediator, some scholars examined these concepts from the social innovation perspective (Seelos \& Mair, 2005; Abu-Saifan, 2012) The discussion on these concepts still often accepts individuals business leaders, politicians, NGO activists - as drivers of change who influence social issues 
(Mulgan et al., 2007, p.13). These individuals need to possess an open and innovative attitude in order to promote social entrepreneurship and social enterprise that realize the social purpose and create social value (Shin, 2018, p.10). However, individual innovativeness is often examined from the perspective of economic value as in studies on innovativeness from the perspective of consumer and producer innovativeness (Blythe, 1999), employee innovativeness (Parzefall, Seeck \& Leppänen, 2008) and individual innovation behavior in the workplace (Yesil \& Sozbilir, 2013). Thus, this study is expected to bring a deeper understanding of the relationship between individual and social innovativeness. From this perspective, this study can be regarded as a preliminary one examining the relationship between individual and social innovativeness.

Midgley and Dowling (1978) argued that the psychological and sociological traits of an individual are related to one's innate innovativeness traits. Moreover, group creativity and individual creativity are mutually related (Woodman, Sawyer, \& Griffin, 1993, p.302). In other words, a group affects individual creativity while one's individual ability to innovate contributes to group creativity. De Jong (2006, pp.29-30) indicated that innovation is a part of personal attributes and that it depends on the personal ability to innovate. However, in the organizational context, individual innovations are influenced by new processes emerging in the whole group. Due to this reason, it can be stated that various organizational and environmental factors have an effect on individual innovation.

The study by Cajaiba-Santana (2014, p.45) examined social innovation from individual, structural and integrated (combined) perspectives. According to the individual perspective, the values and characteristics of the individual are the factors that have the strongest influence on the determination of social innovation.

Moreover, Van der Have and Rubalcaba (2016, p.1924) state that technological innovation also has social aspects. Thakur, Ramendra, Angriawan, Arifin, and Summey (2016, p.2765) emphasized that there is a positive relationship between individual innovativeness and technological innovativeness. Innovative individuals are more susceptible to risks and innovations because of their personal characteristics of curiosity and innovation search. Considering that the concept of technological innovation is closely related to social innovation, it can be assumed that there is a positive relationship between individual innovativeness and social innovativeness.

Tracey and Stott (2017, p.56) outlined a framework for social innovation typology indicating that research considers digital solutions to social issues as social movement organizations make significant investments in digital technology. Rahman et al. (2018, p.242) examined social innovation through the lens of technological innovation and found that innovativeness of individuals can be considered as a predictor of perceived ease of use and perceived usefulness of technological innovations with the social aspect. In the light of 
explanations stated above, this study examines the results of a field study conducted on academicians who are supposed to be a reference point for innovativeness in their organization with the assumption that individual innovativeness can explain social innovativeness behavior of individuals.

In this context the hypothesis that is aimed to examine the relationship between individual innovativeness and social innovativeness and the causality relationship between them is stated as follows:

"There is a positive relationship between individual innovativeness and social innovativeness".

\section{RESEARCH METHODOLOGY}

The main purpose of this research is to examine the relationship between individual innovativeness and social innovativeness of academicians working at Selcuk University, Turkey. The survey method is used as the data collection tool for this study.

According to the literature review students, teachers and academicians are the most popular sample to be selected in order to examine individual innovativeness (Van Rijnsoever \& Donders, 2009; Erdoğan \& Güneş, 2013; Yilmaz \& Bayraktar, 2014; Demiralay, Bayır, \& Gelibolu 2016; Eröz, 2017). Unceta et al. (2016) in their study on RESINDEX model measuring social innovation suggested that the organizational level is more appropriate than national level in measuring social innovation. For these reasons, the university and therefore, the academic staff have been identified as the appropriate sample for this study.

A total number of academicians working at the university as the full-time staff is 1,200 people. A survey method (quantitative) is chosen for this study. 280 questionnaire forms have sent to the academicians working at different faculties during the period of research (November-December 2016). By the end of the data collection process, 242 questionnaires are collected. All 242 questionnaire forms are considered to be acceptable for analysis.

In order to determine the representative sample of the population, a table developed by Yazıcıoğlu and Erdoğan (2004) which contains the sample numbers that can represent the specific population is used. In this context, the sample of 224 for the population of 2500 with the consideration of the sampling error of $\pm 0.05, \mathrm{p}=0.8$ (observing ratio of $\mathrm{X}$ in the population) and $\mathrm{q}=0.2$ (the unobserved ratio of $\mathrm{X}$ in the population) is sufficient. Thus, taking into account that the population contains 1200 people and the sample is 242 , it is considered that the taken sample can represent the given population. 


\section{RESULTS}

\subsection{Demographic Characteristics}

The age of the participants ranges from 23 years old to 63 years old, while the average age is estimated as 36.9. Employment term ranges from 1 year to 39 years. Table 2 below provides detailed information on gender, faculty and academic degree.

Table 2: Demographic characteristics

\begin{tabular}{|l|l|l|}
\hline \multirow{3}{*}{ Gender } & Female & $36.8 \%$ \\
\cline { 2 - 3 } & Male & $63.2 \%$ \\
\hline \multirow{5}{*}{ Faculty } & Faculty of Literature & $11.57 \%$ \\
\cline { 2 - 3 } & Faculty of Engineering & $11.57 \%$ \\
\cline { 2 - 3 } & Faculty of Communication & $11.15 \%$ \\
\cline { 2 - 3 } & Faculty of Science & $11.15 \%$ \\
\cline { 2 - 3 } & Faculty of Law & $11.15 \%$ \\
\cline { 2 - 3 } & Faculty of Architecture & $11.15 \%$ \\
\cline { 2 - 3 } & Faculty of Health Sciences & $11.15 \%$ \\
\cline { 2 - 3 } & Faculty of Veterinary & $10.3 \%$ \\
\cline { 2 - 3 } & Vocational School of Technical Sciences & $3.31 \%$ \\
\cline { 2 - 3 } & Faculty of Agriculture & $2.48 \%$ \\
\cline { 2 - 3 } & Faculty of Economics and Administrative Sciences & $2.26 \%$ \\
\cline { 2 - 3 } & Vocational School of Foreign Languages & $0.83 \%$ \\
\hline Academic degree & Assistant Professors & $73.14 \%$ \\
\cline { 2 - 3 } & Professor Doctors & $14.05 \%$ \\
\cline { 2 - 3 } & Associate Professors & $12.81 \%$ \\
\hline
\end{tabular}

\subsection{Individual Innovativeness}

In order to measure individual innovativeness, 20-items Individual Innovativeness Scale (IIS) is used in this study. The scale developed by Hurt et al. (1977) has been adapted to Turkish by Kılıçer and Odabaşı (2010). The measurement tool uses a Likert scale. For this scale 1 stands for strongly disagree, 2 for disagree, 3 is for neutral, 4 stands for agree and 5 is for strongly agree. The results obtained are tested using SPPS 15.0 statistical software program.

As the original scale items are in English, they are translated into Turkish and compared with the study by Kılıçer and Odabaşı (2010). The obtained Turkish text is reviewed by Selcuk University Foreign Language Higher School (YADAM) teachers, translated into English again and then compared with the original text. The differences in translation are cross-checked and edited as this step is important from the perspective of the validity of the scale. 
Individual Innovativeness Scale (IIS) which is used to identify innovativeness level of individuals and their category of innovation measures innovation in a general sense and characterizes individual innovativeness as "a willingness to try new things". According to this fact, innovation is a response to new and different things, and these responses to change vary from very positive to very negative. In addition, it is considered as a concept related to other personal characteristics such as risk-taking and openness to experiences (Kılıçer \& Odabaşı, 2010).

Innovativeness score measured with the help of IIS is calculated by substracting the total score of negative items from the total score of positive items $(1,2,3,5,8,9,11,12,14,16$, 18 and 19) and adding 42 to the score. Participants are categorized according to the calculated scores. According to Hurt et al. (1977) the score of 80 and higher implies Innovators, the score between 69 and 80 identifies Early Adopters, the score between 57 and 68 determines Early Majority, the score with the range of 46 and 56 implies Late Majority and the score under 46 identifies Laggards. In this context, the categorization of participants according to their innovativeness levels is presented in Table 3.

Table 3: Innovativeness levels of academicians

\begin{tabular}{|l|l|l|}
\hline & Number & Percentage \\
\hline Laggards (score of 45 and under) & 1 & 0.4 \\
\hline Late majority (score of 46-56) & 35 & 14.5 \\
\hline Early majority (score of 57-68) & 115 & 47.5 \\
\hline Early adopters (score of 69-80) & 90 & 37.2 \\
\hline Innovators (score of 81 and higher) & 1 & 0.4 \\
\hline Total & $\mathbf{2 4 2}$ & $\mathbf{1 0 0 . 0}$ \\
\hline
\end{tabular}

A significant part of academicians (47.5\%) is referred to the category of early majority. Due to the fact that the early majority connects late majority and early adopters, this class has an important place in the system. It can be stated that when this category is willing to adopt new ideas the percentage is not underrated. The percentage of early adopters which work as a role model for those in the system in adopting innovations is $37.2 \%$. The percentage of innovators is $0.4 \%$. Considering that academicians are regarded as leaders in adopting innovations this percentage is considered to be quite low. On the other hand, considering the early majority, early adopters and innovators as one, it can be said that a significant part of Selçuk University academicians has evolved from suspiciousness to more rapid adoption of innovations.

The information related to the measurement of scale items on the sample of academicians is demonstrated in Table 4. 
Table 4: Individual innovativeness scale

\begin{tabular}{|l|l|l|}
\hline & Mean & St.dev. \\
\hline My peers often ask me for advice or information. & 3.95 & 0.90 \\
\hline I enjoy trying out new ideas. & 4.22 & 0.80 \\
\hline I seek out new ways to do things. & 4.19 & 0.80 \\
\hline I frequently improvise methods for solving a problem when an answer is not apparent. & 3.59 & 0.94 \\
\hline I feel that I am an influential member of my peer group. & 3.97 & 0.94 \\
\hline I consider myself to be creative and original in my thinking and behavior. & 4.02 & 0.84 \\
\hline I am an inventive kind of person. & 3.81 & 0.94 \\
\hline I enjoy taking part in the leadership responsibilities of the groups I belong to. & 4.05 & 0.90 \\
\hline I find it stimulating to be original in my thinking and behavior. & 3.87 & 0.89 \\
\hline I am challenged by ambiguities and unsolved problems. & 3.05 & 1.20 \\
\hline I am receptive to new ideas. & 4.35 & 0.73 \\
\hline I am challenged by unsolved problems. & 2.82 & 1.15 \\
\hline Total of positive items ${ }^{1}$ & 45.91 & 5.16 \\
\hline I am generally cautious about accepting new ideas. & 3.22 & 1.14 \\
\hline I am suspicious of new inventions and new ways of thinking. & 2.58 & 1.24 \\
\hline $\begin{array}{l}\text { I rarely trust new ideas until I can see whether the vast majority of people around me accepted } \\
\text { them. }\end{array}$ & 2.65 & 1.12 \\
\hline I am aware that I am usually one of the last people in my group to accept something new. & 2.64 & 1.18 \\
\hline $\begin{array}{l}\text { I am reluctant about adopting new ways of doing things until I see them working for people } \\
\text { around me. }\end{array}$ & 3.22 & 1.19 \\
\hline I tend to feel that the old way of living and doing things is the best way. & 2.55 & 1.10 \\
\hline I must see other people using new innovations before I will consider them. & 3.02 & 1.20 \\
\hline I often find myself skeptical of new ideas. & 2.32 & 1.04 \\
\hline Total of negative items ${ }^{2}$ & $\mathbf{2 2 . 2 0}$ & $\mathbf{5 . 1 4}$ \\
\hline
\end{tabular}

Note: (i) $n=242$, (ii) For this scale 1 is strongly disagree and 5 is strongly agree. (iii) According to the two-way ANOVA test of Friedman $\left(\chi^{2}=2435.237 ; p<0.001\right)$ the results are statistically significant.

\subsection{Social Innovativeness}

Halaç et al. in 2014 have developed the Social Innovativeness Scale while checking its validity and reliability. The scale which consists of one dimension and 8 items measures participants' inclinations to social innovation. This measurement tool uses Likert scale; 1 stands for strongly disagree, 2 for disagree, 3 is for neutral, 4 stands for agree and 5 is for strongly agree. The results obtained were tested using SPPS 15.0 statistical software program.

1 Reliability coefficient of the scale was calculated before summarizing scores of positive items of Individual Innovativeness Scale. The Cronbach alfa of 0.712 shows reliability of the scale and that the total score can be calculated thereafter.

2 Reliability coefficient of the scale was calculated before summarizing scores of negative items of Individual Innovativeness Scale. The Cronbach alfa of 0.710 shows reliability of the scale and that the total score can be calculated thereafter. 
The results related to social innovativeness are presented in Table 5. Considering Table 5 , it can be seen that the average of all items except for "I search for opportunities that will make a change in social norms and rules" exceeds 4 . In this context, it can be stated that the level of academicians' participation is high. In other words, their inclination to social innovativeness is high. The minimum score of the scale is 8 and the maximum score is 40 . In this context, the mean of the total score scale is 33.41 , which is close to the maximum score. Therefore, the average value of the total score can be considered as an indicator of high social innovativeness of the academicians.

Table 5: Social innovativeness scale

\begin{tabular}{|l|l|l|}
\hline & Ort. & S.S. \\
\hline I want to develop new products and services with social content to improve society's quality of life. & 4.25 & 0.82 \\
\hline I search for methods to create political and social changes in society. & 4.01 & 0.89 \\
\hline I want to develop new scientific educational techniques to increase the innovative power of society. & 4.34 & 0.78 \\
\hline I use new technologies to solve social problems and find solutions to these problems. & 4.24 & 0.75 \\
\hline I search for ways to improve social solidarity and social participation in society. & 4.17 & 0.81 \\
\hline I search for new ideas that will create social value will make society more effective. & 4.03 & 0.85 \\
\hline I search for opportunities that will make a change in social norms and rules. & 3.90 & 0.84 \\
\hline I would like to be helpful to my surroundings without any financial rewarding. $^{3}$ & 4.48 & 0.74 \\
\hline Total $^{3}$ & $\mathbf{3 3 . 4 1}$ & $\mathbf{6 . 4 8}$ \\
\hline
\end{tabular}

Note: (i) $n=242$, (ii) For this scale 1 is strongly disagree and 5 is strongly agree. (iii) According to the two-way ANOVA test of Friedman $(\chi 2=822.655 ; \mathrm{p}<0.001)$ the results are statistically significant.

\subsection{The Relationship between Individual Innovativeness and Social Innovativeness}

The main purpose of the research is to examine whether there is a relationship between individual innovativeness and social innovativeness. In this regard, in order to determine the relationship between Individual Innovativeness and Social Innovativeness scales, the Pearson correlation coefficient is calculated (each variable maintains the normal distribution condition and Shapiro-Wilk values are estimated as: statistics for Social Innovativeness $=0.892$ and $\mathrm{p}=0.241$; statistics for Positive total $=0.982$ and $\mathrm{p}=0.201$; statistics for Negative total $=0.967$ and $\mathrm{p}=0.228$ and statistics for Individual Innovativeness $=0.970$ and $\mathrm{p}=0.232$ ). The codification of 8 reverse coded items of Individual Innovativeness scale are figured out before the correlation coefficient is calculated. Total individual innovativeness score is calculated thereafter. The results are demonstrated in Table 6 below.

3 Reliability coefficient of Social Innovativeness scale was calculated before summarizing scores. The Cronbach alfa of 0.82 shows reliability of the scale and that the total score can be calculated thereafter. 
Table 6: Correlation matrix

\begin{tabular}{|l|l|l|l|l|}
\hline & Social Innovativeness & Positive total & Negative total & Individual Innovativeness \\
\hline Social Innovativeness & 1 & & & \\
\hline Positive total & $0.575^{\star}$ & 1 & & \\
\hline Negative total & $0.172^{\star}$ & 0.108 & 1 & \\
\hline Individual Innovativeness & $0.503^{\star}$ & $0.748^{\star}$ & $0.741^{\star}$ & 1 \\
\hline
\end{tabular}

Note: ${ }^{\star} \mathrm{p}<0.001$.

Considering the data given in Table 6, it can be stated that there is a positive medium-level and statistically significant $(\mathrm{p}<0.001)$ correlation between Individual Innovativeness and Social Innovativeness scales. It has been also seen that there is a statistically significant ( $p$ $<0.001)$ positive relationship between Social Innovativeness scale and Individual Innovation scale sub-dimensions. In this regard, Table 5 data support the hypothesis that there is a positive relationship between individual innovativeness and social innovativeness.

In order to define a causal relationship between Individual Innovativeness and Social Innovativeness scales the below model is proposed. The regression analysis is carried out thereafter. The classic regression analysis assumptions apply to the error term of $\boldsymbol{E}$. The results of the regression analysis are demonstrated in Table 7.

Social Innovativeness $=b 0+b 1$ Individual Innovativeness $+\varepsilon t$

The proposed model is statistically significant $(\mathrm{p}<.001)$. According to the results of the regression analysis, $\mathrm{R}^{2}$ (percent of variance expounded) and $\mathrm{F}$ (significance level of regression model) values show that Social Innovativeness can be explained by Individual Innovativeness scale. In this regard, the results in Table 6 also support the hypothesis that there is a positive relationship between individual innovativeness and social innovativeness.

Table 7: Regression analysis results

\begin{tabular}{|l|l|l|l|l|l|l|}
\hline Dependent variable & $\mathbf{R}^{2}$ & Independent variables & $\mathbf{B}$ & Std.Error & $\boldsymbol{t}$ & $\mathbf{F}$ \\
\hline \multirow{2}{*}{ Social Innovativeness } & \multirow{2}{*}{0.250} & Constant Term & 13.818 & 2.184 & $6.327^{*}$ & \multirow{2}{*}{$81.379^{*}$} \\
\cline { 3 - 8 } & & Individual Innovativeness & 0.273 & 0.030 & $9.021^{*}$ & \\
\hline
\end{tabular}

Note: ${ }^{*} \mathrm{p}<0.001$

The examination of the relationship between Social Innovativeness scale and sub dimensions of Individual Innovativeness scale is considered important for better understanding the question of the research. Due to this reason the following model is proposed:

Social Innovativeness $=b 0+b 1$ Pos.Ind.Innovativeness $+b 2 \mathrm{Neg}$. Ind.Innovativeness $+\varepsilon t$ 
The multiple regression analysis is carried out thereafter. The classic regression analysis assumptions apply to the error term of $\mathcal{E}$. The results of the multiple regression analysis are demonstrated in Table 8.

Table 8: Multiple regression analysis results

\begin{tabular}{|l|l|l|l|l|l|l|}
\hline Dependent variable & $\mathbf{R}^{2}$ & Independent variables & $\mathbf{B}$ & Std.Error & $\boldsymbol{t}$ & $\mathbf{F}$ \\
\hline \multirow{3}{*}{ Social innovativeness } & \multirow{3}{*}{0.337} & Constant Term & 10.313 & 2.144 & $4.811^{*}$ & \\
\cline { 3 - 7 } & & Positive Individual Innovativeness & 0.452 & 0.042 & $10.661^{*}$ & \multirow{2}{*}{$62.236^{*}$} \\
\cline { 3 - 7 } & & Negative Individual Innovativeness & 0.091 & 0.043 & $2.114^{* *}$ & \\
\hline
\end{tabular}

Note: ${ }^{\star} \mathrm{p}<0.001,{ }^{* \star} \mathrm{p}<0.05$

The proposed model is statistically significant $(\mathrm{p}<0.001)$. According to the results of regression analysis $\mathrm{R}^{2}$ (percent of variance expounded) and $\mathrm{F}$ (significance level of regression model) values demonstrate that Social Innovativeness can be explained by sub-dimensions of Positive Individual Innovativeness and Negative Individual Innovativeness.

\section{CONCLUSION}

Innovations and changes that emerge in society affect not only the society itself but every individual in particular. For this reason, it is pivotal for organizations to motivate their employees to be ready for new ideas, products, and services as well as to develop their adaptiveness to them. In other words, it is necessary for the organizations to keep organizational structure and strategy engaged in processes stimulating new ways of thinking and producing new ideas. Moreover, many scholars have indicated the significance of innovation and innovativeness for an organization (Coakes, Smith, \& Alwis, 2011, p.32; Prange \& Pinho, 2017, p.1120) for providing a competitive advantage and higher performance (Hurley \& Hult, 1998, p.45; Cai, Chen, Chen, \& Bruton, 2017, p.113).

Studies examining the topic of innovativeness emphasize the great importance of innovations both for society and organizations. Likewise, the literature demonstrates that now organizations credit social innovations as a mean for creating favorable outcomes for the public and private sector (Matei \& Antonie, 2015, p.64). Considering the public sector, social innovations can make a great contribution to the development of the whole society as well as local communities in order to address social needs. Social innovations can facilitate knowledge dissemination, generate new solutions in healthcare, create job opportunities, reduce poverty and foster economic growth on a national level. Regarding the private sector, social innovations are thought to facilitate the organization's competitive advantage and its reputation. The application of social innovation in the organization may be beneficial in both ways: as employees are regarded as the core of the organization they can be considered as drivers of innovations directed towards society. 
Nevertheless, according to the literature review, the causal relationship between individual innovativeness and social innovativeness has not been investigated yet. In this context, the main aim of this study is to examine the relationship between individual and social innovativeness along with the causality relationship between these two variables. According to Unceta et al. (2016, p.6) organizational approach is rather more appropriate to measure social innovation than an individual or national one: individual approach is inadequate due to the lack of actors' participation and the national one is inappropriate as they "measure the context of social innovation but not social innovation itself". Furthermore, when assessing innovation and innovativeness it was necessary to select a sample which is considered to be innovative. As academicians play a significant role in seeking, distributing and sharing information and knowledge, and knowledge itself takes an important place in organizational learning and innovation activities (Lam, 2000, p.487), academicians have been chosen as a sample for this study.

This paper's findings provide some insights in regards to the diffusion of innovation and innovativeness data. Most of the academic staff can be categorized as the early majority (47.5 $\%$ ) and as early adopters (37.2\%), while late majority covered $14.5 \%$, and laggards and innovators covered the percentage of $0.4 \%$ respectively. The result appeared to be inconsistent with the assumption that most academicians are innovators; however, the fact that most of the sample taken was in the early majority and early adopters groups (84.7\%) supports the assumption that academicians have high - or medium-level individual innovativeness.

Despite the fact that social innovation happened to gain a peculiar interest of researchers, the topic of social innovativeness has not been closely analyzed. This study's results manifest that the level of social innovativeness of all of the items is medium and high. This finding demonstrates that employees are inclined to seek new ways of improving society's quality of life, therefore contributing both to organizational and public interests.

There is a positive, medium-level statistically significant relationship between social innovativeness and individual innovativeness. Additionally, findings contend that social innovativeness level depends on the level of individual innovativeness. The hypothesis of this study was confirmed by the result that the higher individual innovativeness triggers an individual to search for new ways of improvement in society. This fact implies that organizations can stimulate their employees to seek solutions to social issues by encouraging them to adopt innovations and generate new ideas inside the organization. Considering the fact that organizations are in constant search for advanced methods of differentiating their products and services, this finding contributes to the understanding of innovation application in an organization's strategy.

Despite the fact that social innovativeness results are on medium and high levels, still, individual innovativeness findings did not demonstrate the expected results. Considering the 
assumption that academicians are the ones who create the value of knowledge in society and stimulate its diffusion along with innovation, these values are presumed to be on a higher level. As the results demonstrate substantial attention have to be paid to the development of individual innovativeness rather than a social one. Additionally, regarding the fact that academicians can be referred to as a source of knowledge to students, it is crucial for academic staff to be "innovators" and "early adopters". One of the suggestions that can also be verified by further academic research would be to make a cultural and educational exchange with countries with high innovativeness index in society. Another suggestion would be to cultivate innovation activities in universities as working on projects requiring creating social and technological value. Furthermore, one of the recommendations would be to constantly make thorough research and participate in conferences aimed at contemporary topics.

It is important to note some of the limitations of this study that future research can address. Considering the fact that this study is conducted only in one university, a potential shortcoming of this study is the sample size as the data for this study has been collected only from one university in Turkey. Moreover, one might find helpful some suggestions for future studies related to this field. One might investigate the relationship between individual and social innovativeness in a different scope, e.g. selecting the sample of another professional group or organizational structure.

In order to extend the generalizability of the study, future research of this kind might focus on different countries and cultures such as a western one in order to make a comparison and verify the results. Furthermore, one might expand the scope of the research by not only investigating the relationship between social and individual innovativeness but adding other mediators into the model.

\section{References}

Abernathy, W. J. \& Clark, K. B. (1985). Innovation: Mapping the winds of creative destruction. Research Policy, 14(1), 3-22.

Abu-Saifan, S. (2012). Social entrepreneurship: Definition and boundaries. Technology Innovation Management Review, 2(2), 22-27

Al Mamun, A., Muniady, R., Yukthamarani, P. P., Noor Raihani Binti, Z. \& Mohamad, M. R. (2016). Micro-enterprise development initiatives and entrepreneurial competencies, innovativeness, and social capital in Malaysia. Development in Practice, 26(8), 1094-1110.

Amabile, T. M. (1988). A model of creativity and innovation in organizations. Research in Organizational Behavior, 10(1), 123-167.

Baregheh, A., Rowley, J. \& Sambrook, S. (2009). Towards a multidisciplinary definition of innovation. Management Decision, 47(8), 1323-1339. 
Blythe, J. (1999). Innovativeness and newness in high-tech consumer durables. Journal of Product \& Brand Management, 8(5), 415-429.

Bright, D. S. \& Godwin, L. N. (2010). Encouraging social innovation in global organizations: Integrating planned and emergent approaches. Journal of Asia-Pacific Business, 11(3), 179196.

Bund, E., Gerhard, U., Hoelscher, M. \& Mildenberger, G. (2015). A methodological framework for measuring social innovation. Historical Social Research/Historische Sozialforschung, 40(3), 48-78.

Cai, L., Chen, B., Chen, J. \& Bruton, G. D. (2017). Dysfunctional competition \& innovation strategy of new ventures as they mature. Journal of Business Research, 78, 111-118.

Cajaiba-Santana, G. (2014). Social innovation: Moving the field forward. A conceptual framework. Technological Forecasting and Social Change, 82, 42-51.

Capaldo, A. \& Petruzzelli, A. M. (2011). In search of alliance-level relational capabilities: Balancing innovation value creation and appropriability in R\&D alliances. Scandinavian Journal of Management, 27(3), 273-286.

Coakes, E. W., Smith, P. A. \& Alwis, D. (2011). Sustainable innovation and right to market. Information Systems Management, 28(1), 30-42.

Celik, K. (2013). The relationship between individual innovativeness and self-efficacy levels of student teachers. International Journal of Scientific Research in Education, 6(1), 56-67.

De Jong, J. (2006). Individual Innovation. The connection between leadership and employees' innovative work behavior. European Journal of Innovation Management, 10(1), 41-64.

Demiralay, R., Bayır, E. A. \& Gelibolu, M. F. (2016). Öğrencilerinin bireysel yenilikçilik özellikleri ile çevrimçi öğrenmeye hazır bulunuşlukları ilişkisinin incelenmesi. Eğitim ve Öğretim Araştırmaları Dergisi, 5(1), 161-167.

Dibrell, C., Craig, J. B., Kim, J. \& Johnson, A. J. (2015). Establishing how natural environmental competency, organizational social consciousness, and innovativeness relate. Journal of Business Ethics, 127(3), 591-605.

Erdoğan, D. G. \& Güneş, D. Z. (2013). The relationship between individual innovatiness and change readiness conditions of students attending faculty of education. Procedia-Social and Behavioral Sciences, 106, 3033-3040.

Eröz, S. S. (2017). The relationship between individual innovativeness and locus of control: A research on tourism faculty students. Journal of Tourism and Hospitality Management, 5(1), 46-52.

European Commission (2010). This is social innovation. Brussels. https://youngfoundation.org/ publications/this-is-european-social-innovation/

Gilbert, D. H. (2007). Firm innovativeness in SMES: Lessons from Japan. International Journal of Organisational Behaviour, 12(1), 126-143. 
Goldsmith, R. E., \& Foxall, G. R. (2003). The measurement of innovativeness. in Shavinina L.V. (Ed.), The International Handbook of Innovation. Oxford: Elsevier, 321-328.

Halaç, Duygu S., Eren, H. \& Bulut Ç. (2014). Sosyal yenilikçilik bir ölçek geliştirme çalışması, Hacettepe Üniversitesi İktisadi ve İdari Bilimler Fakültesi Dergisi, 32(1), 165-190.

Hannan, A., English, S. \& Silver, H. (1999) Why innovate? Some preliminary findings from a research project on 'innovations in teaching and learning in higher education, Studies in Higher Education, 24(3), 279-289.

Heunks, F. J. (1998). Innovation, creativity and success. Small Business Economics, 10(3), 263-272.

Hurley, R. F. \& Hult, G. T. M. (1998). Innovation, market orientation, and organizational learning: An integration and empirical examination. The Journal of Marketing, 62(3), 42-54.

Hurt, H. T., Joseph, K. \& Cook, C. D. (1977). Scales for the measurement of innovativeness. Human Communication Research, 4(1), 58-65.

Kılıçer, K. \& Odabaşı, H. F. (2010). Bireysel yenilikçilik ölçeği (BYÖ): Türkçeye uyarlama, geçerlik ve güvenirlik çalışması. Hacettepe Üniversitesi Eğitim Fakültesi Dergisi, 38, 150-164

Kocziszky, G. \& Somosi, M. V. (2016). Generating social innovation with knowledge engineering. Procedia-Social and Behavioral Sciences, 223, 167-174.

Lam, A. (2000). Tacit knowledge, organizational learning and societal institutions: An integrated framework. Organization Studies, 21(3), 487-513.

Leadbeater, C. (2007). Social enterprise and social innovation: Strategies for the next ten years. $A$ social enterprise think piece for the Cabinet Office of the Third Sector.

Lisetchi, M. \& Brancu, L. (2014). The entrepreneurship concept as a subject of social innovation. Procedia-Social and Behavioral Sciences, 124, 87-92.

London, M. (2012). CSR partnership initiatives. Organizational Dynamics, 3(41), 220-229.

Manning, K. C., Bearden, W. O. \& Madden, T. J. (1995). Consumer innovativeness and the adoption process. Journal of Consumer Psychology, 4(4), 329-345.

Matei, A. \& Antonie, C. (2015). Complexity theory and the development of the social innovation. Procedia-Social and Behavioral Sciences, 185, 61-66.

Midgley, D. F. \& Dowling, G. R. (1978). Innovativeness: The concept and its measurement. Journal of Consumer Research, 4(4). 229-242.

Mulgan, G. (2006). The process of social innovation. Innovations: Technology, Governance, Globalization, 1(2), 145-162.

Mulgan, G., Tucker, S., Ali, R., \& Sanders, B. (2007). Social innovation: What it is, why it matters and how it can be accelerated, Skoll Centre for Social Entrepreneurship. Oxford Said Business School. London: Young Foundation.

Organisation for Economic Co-operation and Development. (2005). Oslo Manual: Guidelines for Collecting and Interpreting Innovation Data. 3rd Edition. Paris: OECD. 
Parzefall, M. R., Seeck, H. \& Leppänen, A. (2008). Employee innovativeness in organizations: A review of the antecedents. Finnish Journal of Business Economics, 2(08), 165-182.

Pater, R. \& Lewandowska, A. (2015). Human capital and innovativeness of the European Union regions. Innovation: The European Journal of Social Science Research, 28(1), 31-51.

Phillips, W., Lee, H., Ghobadian, A., O’Regan, N. \& James, P. (2015). Social innovation and social entrepreneurship: A systematic review. Group \& Organization Management, 40(3), 428461.

Phillis, J. A., Deiglmeier, K. \& Miller, D. T. (2008). Rediscovering social innovation Stanford Social Innovation Review, 6(4), 34-43.

Pierce, J. L. \& Delbecq, A. L. (1977). Organization structure, individual attitudes and innovation. Academy of Management Review, 2(1), 27-37.

Prange, C. \& Pinho, J. C. (2017). How personal and organizational drivers impact on SME international performance: The mediating role of organizational innovation. International Business Review, 26(6), 1114-1123.

Rahman, S. A., Taghizadeh, S. K., Ramayah, T. \& Alam, M. M. D. (2017). Technology acceptance among micro-entrepreneurs in marginalized social strata: The case of social innovation in Bangladesh. Technological Forecasting and Social Change, 118, 236-245.

Roehrich, G. (2004). Consumer innovativeness: Concepts and measurements. Journal of Business Research, 57(6), 671-677.

Rogers, E. (1971). Diffusion of Innovations. 2nd edition. New York: The Free Press.

Salim Saji, B. \& Ellingstad, P. (2016). Social innovation model for business performance and innovation. International Journal of Productivity and Performance Management, 65(2), 256-274.

Scott, S. G. \& Bruce, R. A. (1994). Determinants of innovative behavior: A path model of individual innovation in the workplace. Academy of Management Journal, 37(3), 580-607.

Seelos, C. \& Mair, J. (2005). Social entrepreneurship: Creating new business models to serve the poor. Business Horizons, 48(3), 241-246.

Shavinina, L.V. \& Seeratan, K. L. (2003). On the nature of individual innovation. In Shavinina, L.V. (Ed.) The International Handbook on Innovation. Oxford: Elsevier, 31-43

Shin, C. (2018). How social entrepreneurs affect performance of social enterprises in Korea: The mediating effect of innovativeness. Sustainability, 10(8), 2643.

Sinkovics, N., Sinkovics, R. R. \& Yamin, M. (2014). The role of social value creation in business model formulation at the bottom of the pyramid-implications for MNEs?. International Business Review, 23(4), 692-707. 
Standing, C., Jackson, D., Larsen, A. C., Suseno, Y., Fulford, R. \& Gengatharen, D. (2016). Enhancing individual innovation in organisations: A review of the literature. International Journal of Innovation and Learning, 19(1), 44-62.

Steenkamp, J. B. E., Hofstede, F. T. \& Wedel, M. (1999). A cross-national investigation into the individual and national cultural antecedents of consumer innovativeness. The Journal of Marketing, 63(2), 55-69.

Thakur, R., Angriawan, A. \& Summey, J. H. (2016). Technological opinion leadership: The role of personal innovativeness, gadget love, and technological innovativeness. The Journal of Business Research, 69(8), 2764-2773.

The Young Foundation (2012). Social Innovation Overview - Part I: Defining social innovation. A deliverable of the project TEPSIE. Brussels: European Commission. http://www.tepsie. eu/images/documents/TEPSIE.D1.1.Report.DefiningSocialInnovation.Part $\% 201 \% 20$ -\%20defining\%20social\%20innovation.pdf

Tracey, P. \& Stott, N. (2017). Social innovation: A window on alternative ways of organizing and innovating. Innovation, 19(1), 51-60.

Unceta, A., Castro-Spila, J. \& García Fronti J. (2016). Social innovation indicators. Innovation: The European Journal of Social Science Research, 29(2), 192-204

Uzkurt, C. (2017). Yenilik (İnovasyon) Yönetimi ve Yenilikçi Örgüt Kültürü (Kültürel, Yönetimsel ve Makro Yaklaşım). İstanbul: Beta Yayınları.

Vandecasteele, B. \& Geuens, M. (2010). Motivated Consumer Innovativeness: Concept, measurement, and validation. International Journal of Research in Marketing, 27(4), 308318

Van der Have, R.P. \& Rubalcaba, L. (2016) Social innovation research: An emerging area of innovation studies? Research Policy, 45(9), 1923-1935.

Van Rijnsoever, F. J. \& Donders, A. R.T. (2009). The effect of innovativeness on different levels of technology adoption. Journal of the American Society for Information Science and Technology, 60(5), 984-996.

Van Wijk, J., Zietsma, C., Dorado, S., de Bakker, F. G. \& Martí, I. (2018). Social innovation: Integrating micro, meso, and macro level insights from institutional theory. Business \& Society, forthcoming, 1-32.

Wang, C. L. \& Ahmed, P. K. (2004). The development and validation of the organisational innovativeness construct using confirmatory factor analysis. European Journal of Innovation Management, 7(4), 303-313.

Waychal, P., Mohanty, R. P. \& Verma, A. (2011). Leading indicators of innovation as a competence for individuals: An empirical study. Journal of Advances in Management Research, 8(2), 301-322. 
Winby, S. \& Worley, C. G. (2014). Management processes for agility, speed, and innovation. Organizational Dynamics, 3(43), 225-234.

Woodman, R. W., Sawyer, J. E. \& Griffin, R. W. (1993). Toward a theory of organizational creativity. Academy of Management Review, 18(2), 293-321.

Yesil, S. \& Sozbilir, F. (2013). An empirical investigation into the impact of personality on individual innovation behaviour in the workplace. Procedia-Social and Behavioral Sciences, $81,540-551$.

Yilmaz, O. \& Bayraktar, D. M. (2014). Teachers' attitudes towards the use of educational technologies and their individual innovativeness categories. Procedia-Social and Behavioral Sciences, 116, 3458-3461.

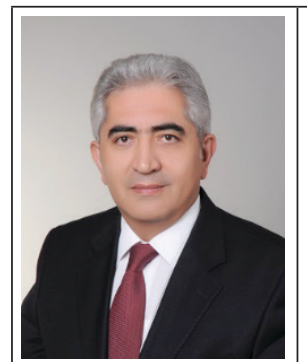

Vural ÇAĞLIYAN - vcagliyan@selcuk.edu.tr

Vural Çağllyan received his B.S. degree in Forest Industries Engineering from Karadeniz Technical University (1998), his Master's degree in Production Management and Marketing from Selcuk University (2002) and PhD degree in Management from Selcuk University (2009). He is an Associate Professor in the Department of Production Management and Marketing in the Faculty of Management and Economics at Selcuk University. He teaches Scientific Methods of Research, Statistical Modeling in Social Sciences, Numerical Methods, and Quality and Innovation Management for undergraduate and graduate students.

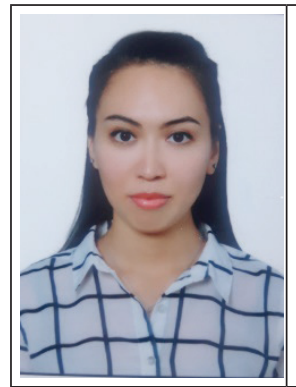

Eldana ESENALİEVA - eldanamaxim@gmail.com

Eldana Esenalieva received her B.A. degree from the American University of Central Asia (2014). She is currently pursuing her Master's degree in the Department of Production Management and Marketing in the Faculty of Management and Economics at Selcuk University. Her fields of interest include Marketing, Innovation, and Entrepreneurship.

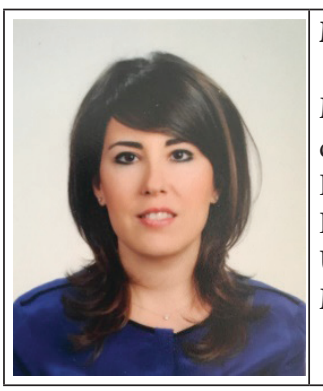

Melis ATTAR - melisattar@selcuk.edu.tr

Melis Attar received her B.A. degree in Economics from Koc University (2003), her M.Sc. degree in International Management from Essex University (2005) and her PhD degree in Business Management from Selcuk University (2014). She is an Assistant Professor in the Department of International Trade in the Faculty of Management and Economics at Selcuk University. She teaches International Management, Entrepreneurship, Organization and Management, Behavioral Science, Business Management, and Leadership practices. 